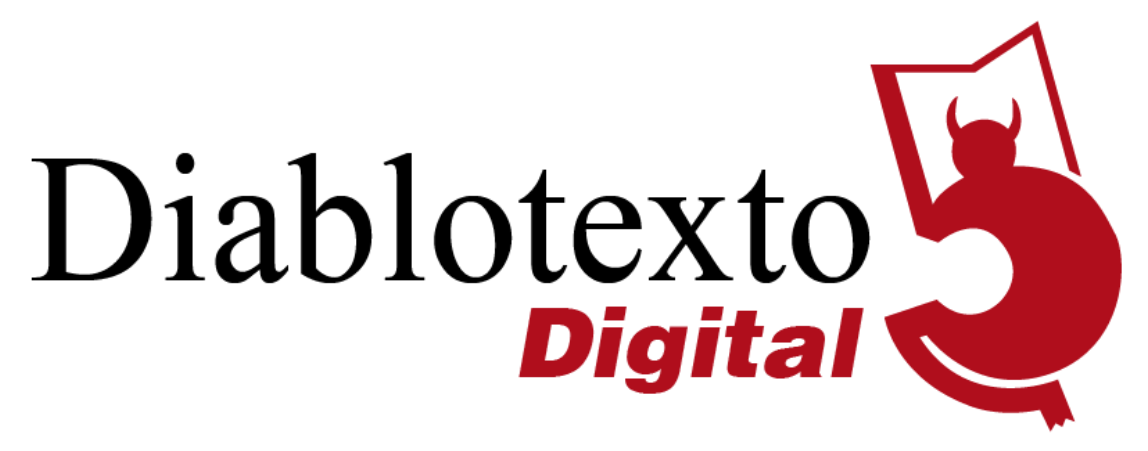

\title{
ALFONSO LÓPEZ: MALVADOS E IMBÉCILES. LOS MEJORES AÑOS DE NUESTRA CRISIS
}

Barcelona: Amaníaco Ediciones, 2015, 160 pp.

\author{
JORDI RIERA PUJAL \\ TEBEOSFERA
}

De pequeños en la escuela los maestros nos enseñan a poner color en los dibujos sin salirnos de la raya. Alfonso López (1950), ya desde principios de los años 70, al poco de trasladarse de su Lleida natal a Barcelona, vio claro que lo suyo sería batallar por expandir esas rayas limitadoras que marcan el sistema socio político en nuestra sociedad. En los dibujos publicados en Malvados e imbéciles. Los mejores años de nuestra crisis (Amaníaco Ediciones, Barcelona, 2015), López sigue sin cumplir lo de no intentar pasarse de la raya, ni en la reflexión que nos propone en sus dibujos, ni en su forma. Gráficamente, el color de la acuarela en sus viñetas o no llega a la raya, o simplemente la desborda.

Malvados e imbéciles es una recopilación de pensamientos gráficos, según palabras del autor, publicados en el diario Público, los más antiguos en su edición de papel (2008-2012), los más recientes en su versión digital (20122014). Junto a estos dibujos hay otras viñetas publicadas en otros medios. Además, siguiendo la estela marcada por los libros de sus admirados Jaume Perich o Chumy Chúmez, ha añadido unos textos costumbristas que retratan la tendencia al absurdo del comportamiento humano. El chiste gráfico se denomina acudit en catalán, que se puede traducir con la palabra "ocurrencia". Esta columna de opinión en la prensa nos propone una propuesta de reflexión o una 
opinión sin matices, directa, entendedora, pero que requiere de una larga elaboración en la mente del autor para no caer en lo obvio de la primera idea o de la humorada fácil. Estos acudits en el caso de A. López buscan la atención del lector para lograr que salga de su indiferencia. Pueden provocar la sonrisa o no, pero siempre buscan tener la gracia de una chispa que pueda intentar promover una toma de conciencia por parte del lector.

El humor gráfico basado en la actualidad política es un arte efímero por definición. El referente que motiva el chiste gráfico y que está en la cabeza tanto del autor como del lector en el momento de publicarse, puede caer en el olvido rápidamente sepultado por el aluvión constante de nuevas noticias. El autor, asumiendo esa caducidad en el libro, ha escogido de su obra las viñetas que mantienen su ingenio y que por seguir estando de actualidad no necesitan de explicaciones contextualizadoras que les harían perder su espontaneidad. Son dibujos que están dirigidos a un público determinado, que sin duda no es el mayoritario. Hablamos de los lectores que escogen la opción de leer el diario www.publico.es, o que los ven cuando algunos de los seguidores del dibujante lo airean en las redes sociales. La complicidad de un lector formado, que sigue la actualidad y que tiene una visión crítica de nuestra sociedad es fundamental para que adquieran todo su sentido.

El libro Malvados e imbéciles no sigue un orden cronológico, sino que agrupa las viñetas por líneas argumentales. Los temas son: la crisis, la crisis y la banca, el sistema, marca España, la cosa cotidiana, mundo maravilloso y adiós, democracia, adiós.

El autor, ya en el lejano 1975 con un franquismo todavía vivo, fundó y coordinó la revista Butifarra! con la colaboración de la Federació d'Associacions de Veïns de Barcelona (FAVB). La publicación rebosaba sátira política dibujada desde una visión izquierdista y de compromiso social. En Butifarra! se plasmaba mediante el humor sin concesiones, la crítica social y la denuncia de los problemas y reivindicaciones de los barrios y de la clase obrera. Los colaboradores de la revista marchaban armados con su lápiz desde la sede de la redacción a las barriadas de la zona metropolitana de Barcelona. Eran entonces zonas donde la ciudad perdía su nombre, que habían crecido 
desmesuradamente en la década anterior y a principios de los setenta. En estos barrios hablaban con los vecinos de las carencias y problemas de la zona que habitaban. Se trataba de hacer un retrato vivo de unos entornos sociales nacidos a consecuencia de la llegada masiva de inmigrados que habían despertado el afán de los especuladores inmobiliarios y, que carecían de los más elementales servicios ciudadanos; calles sin asfaltar, zonas sin escuelas, sin hospitales, casi sin transporte público. Estas diversas problemáticas se veían posteriormente plasmadas no en crónicas textuales periodísticas, sino en viñetas de humor gráfico o en historietas. El libro actual refleja una lucha parecida, aunque los "malvados" en terminología del autor, han mutado de ser franquistas a neoliberales. López no olvida que los avances sociales en democracia han sido notables y en su trabajo actual intenta reflejar que los tiempos son mucho más sibilinos y llenos de matices que en los años setenta, escogiendo una actitud con algo más de distancia con las soluciones y propuestas "salvadoras" de la actual izquierda política.

Alfonso López es garantía de calidad gráfica. Sus trazos contundentes, estilizados, sueltos, son de una alta expresividad, no buscan una pura belleza estética sino la plena conexión con su mensaje. La viñeta es entendida como un flash visual al servicio de una opinión. El autor usa una paleta de colores determinada, son las acuarelas que ha ido depurando con el curso de una larga experiencia como dibujante. Con las acuarelas no parece buscar una fácil belleza visual, sino lograr un interesante expresionismo de colores matizados que contraste con un negro intenso. Alfonso López tiene oficio, sus dibujos denotan que le gusta contar historias, en sus viñetas uno siempre puede imaginar que hay toda una historia detrás de sus personajes y de las situaciones en que se encuentran.

La eterna y simpática risa del autor en su contacto cotidiano no esconde una ironía inteligente y responsable en sus comentarios. Pero, la apariencia puede ser engañosa, en sus trabajos la visión con bastante mala leche (siempre matizada por el humor) abunda, el ataque contra la derecha y contra sus aliados (grandes inversores mundiales, grandes corporaciones, la bolsa, la clase política establecida y sus tentáculos...) es brutal, sin paños calientes. 
Para un veterano revolucionario como Alfonso López, que ha vivido temporadas en países como Nicaragua, Chiapas (México), El Salvador, Ecuador, Bolivia, Perú, colaborando con organizaciones sociales y ayudando a comunidades rurales e indígenas, el momento actual de apatía de las clases menos pudientes puede ser desconcertante. Existe una relativa calma social enfrente de temas como la recesión económica, el paro, los recortes en los servicios por parte de la administración, la corrupción política, la situación internacional o el cambio climático. Al autor le cuesta entender cómo con la situación actual se acaba votando siempre a los mismos. Una posible explicación puede ser el hecho de la existencia de una sociedad civil atrapada en unos medios de comunicación en su inmensa mayoría dóciles con el poder, en que las personas tienen miedo a perder lo poco que tienen y por esa razón aceptan estoicamente disfrutar de los mesurados placeres que puede dar el consumismo low cost, la televisión de puro entretenimiento, el espectáculo del deporte. El título de malvados (que al parecer también incluye a muchos imbéciles), es muy fácilmente discernible a quienes los atribuye el autor (los agentes del neoliberalismo y sus colaboradores). El de imbéciles o torpes creo que se nos adjudica a todos como responsables de que sigan ganando las elecciones los que prometen seguir con las mismas políticas que nos han llevado a la crisis.

Esta reseña es solo una serie de opiniones del autor del artículo, son visiones subjetivas que ciertamente solo atinan a vislumbrar una parte de los contenidos que nos ofrece Alfonso López. Lo mejor es ir al original, y citando el título de una colección de álbumes de cómic de compromiso social del autor, Pasen y Vean, es cuestión de adentrarse sin prejuicios en esta obra densa que rehúye la superficialidad. Se trata de una propuesta que es aconsejable saberse dosificar. Si nos sumergimos en él, se puede ver una interesante aportación para formarse una opinión crítica de esta larga crisis que estamos padeciendo y de los rasgos de estupidez humana que forman parte de nuestro ADN como sociedad. El libro nos propone que nos cuestionemos como individuos, que nos preguntemos sobre el cómo hemos podido llegar a la situación actual y también que nos impliquemos en la lucha para mejorar la sociedad de la que todos formamos parte. 